\title{
Interaction Reaction Between Different Sowing Date and Weed Management Methods in Drum-Seeded Boro Rice (Oryza sativa L.)
}

\author{
P. S. Bera, S. Bandyopadhyay*, C. K. Kundu, P. Bandopadhyay and B. Pramanick
}

Dept. of Agronomy, Faculty of Agriculture, B.C.K.V., Mohanpur Nadia, W.B. (741 252), India

\section{Article History}

Manuscript No. AR1507

Received in $23^{\text {rd }}$ December, 2015

Received in revised form $4^{\text {th }}$ April, 2016

Accepted in final form $5^{\text {th }}$ April, 2016

\section{Correspondence to}

"E-mail: sahuji.ag@gmail.com

\section{Keywords}

Boro Rice, drum-seeding, sowing date, weed, interaction

\begin{abstract}
A field experiment was conducted during boro seasons of 2004-05 and 2005-06 to find out the effects of four different date of sowing and three non-chemical weed control methods and also their interaction effects on weed flora, yield and economics of drum seeded bororice at BCKV, Mohanpur, Nadia, West Bengal, India in a split plot design. The sowing of rice was done under puddled condition by using drum-seeder, which is an upgraded device for rice sowing. Sowing of rice on $15^{\text {th }}$ December produced minimum weed density and biomass at both of the observations, maximum $\%$ of effective tillersand B:C ratiocompared to other dates of sowing. Though the highest grain $\left(5.19 \mathrm{t} \mathrm{ha}^{-1}\right)$ and straw $\left(5.65 \mathrm{t} \mathrm{ha}^{-1}\right)$ yields obtained from $1^{\text {st }}$ December sowing, but itwas closely followed by $15^{\text {th }}$ December sowing. Amongst non-chemical weed control methods, hand-weeding gave lowest weed population and dry matter $\mathrm{m}^{-2}$ at 30 and 60 DAS, which were statistically comparable with mechanical-weeding with Japanese paddy weeder. On the other hand, mechanical-weeding produced highest grain and straw yield as well as B:C ratio. In case of interaction effects of the treatments, $15^{\text {th }}$ December sowing coupled with hand weeding gave minimum weed population $\mathrm{m}^{-2}$ followed by $1^{\text {st }}$ December sowing with hand weeding treatments at both 30 and 60 DAS. Sowing of drum-seeded rice on $1^{\text {st }}$ December along with weeding by using Japanese Paddy Weeder produced higher grain yields (6.07 tha $\left.{ }^{-1}\right)$, net return ( $\left.₹ 29265\right)$ and $\mathrm{B}: \mathrm{C}$ ratio (1.41) ascompared to other treatment combinations under the experiment.
\end{abstract}

\section{Introduction}

Rice (Oryza sativa L.) is the leading cereal of the world (Ashraf et al., 2006), and more than half of the human race depend on rice for their daily sustenance (Chauhan and Johnson, 2011). It is the primary source of income and employment for more than 100 million households in Asia and Africa (FAO, 2004). World's rice demand is projected to increase by $25 \%$ from 2001 to 2025 to keep pace with population growth (Maclean et al., 2002). To meet increasing rice demand in a sustainable way with shrinking natural resources is a great challenge. In recent years, traditional transplanting of rice in many Asian countries, including India, is being replacedby direct seeding because of higher transplanting cost. This method of sowing can be done by drilling the seeds in line eithermanually or with the use of simple plastic made implement known as drum seeder (Balasubramanian et al., 2003), which reduces labour requirement, improves emergence of seeds, and reduces lodging to less than $10 \%$ (Bakker et al., 2002). Weeds are the greatest yield-limiting constraint to rice among various factors. In tropic, average rice yield losses due to weeds is $35 \%$ (Oerke and Dehne, 2004). According to Mamun et al., 1993 , weed growth reduced the grain yield by $68-100 \%$ for DSR, $22-36 \%$ for modern 'boro' rice. To manage the weed problem; different weed control options are available for rice. In our country, use of herbicide is the most effective, economic and practical way of weed management (Marwat et al., 2006; Hussain et al., 2008; Anwar et al., 2012) but intensive use of herbicides may result in development of resistant weed biotypes (Heap, 2006), crop phytotoxicity (Begum et al., 2008), environment pollution and public health hazard (Phuong et al., 2005). Among different non-chemical weed management practice; though hand-weeding is most important method for weed removal in rice but because of scarcity of agricultural workers, hand-weeding is not economicalnow (Farooq et al., 2011) as it is very expensivewith rise of wage rate (Roder and Keobulapha, 1997). Other problems include delayed weeding due to unavailability of labor, damage to the rice seedlings and mistaken removal of rice seedlings 
(Moody and Cordova 1985). As such, mechanical method of weeding could be a good alternative of hand weeding and those agronomic tools help to increase competitive ability of crop against weeds (Liebman et al., 2001), and at the same time are eco-friendly towards the environment and economic. The time of sowing have noticeable impact on weed intensity, crop growth and probably yield also. Seeding of rice at the optimum time is veryimportant for obtaining high yield and good quality kernels (Chauhan, 2012). The decreasing trend in the grain yield due to delayed seeding might be associated with significantly lower number of panicles $\mathrm{m}^{-1}$, less number of filled grains panicle ${ }^{-1}$ and low grain weight (Mishri and Kailash, 2005). So the method of crop establishment, sowing time and method of weed management has a great impact on boro rice cultivation to ensure maximum return. Keeping the above in mind the present experiment were undertaken to study the effect of time of sowing and non-chemical weed management practices on drum seeded boro rice which may helps to the farmers to make the decision of sowing time and weed management method under a improved crop establishment methodto ensure maximum return.

\section{Materials and Methods}

The field experiment was conducted during boro seasons of 2004-05 and 2005-06 at the Instructional Farm, Bidhan Chandra Krishi Viswavidyalaya, Mohanpur, Nadia, West Bengal, geographically situated at $22^{\circ} 93^{\prime} \mathrm{N}$ latitude and $88^{\circ} 53^{\prime}$ E longitude with an elevation of $9.75 \mathrm{~m}$ above Mean Sea Level. The experiment were conducted on the same location with a fixed lay-out plan in both the years. The soil of the experimental site was sandy clay loam in texture with $\mathrm{pH}$ value of 6.8 and it falls in the new alluvial zone with medium fertility status having $0.63 \%$ organic $\mathrm{C}, 0.056 \%$ total $\mathrm{N}, 18.35 \mathrm{~kg} \mathrm{ha}^{-1}$ available $\mathrm{P}$ and $135.45 \mathrm{~kg} \mathrm{ha}^{-1}$ available $\mathrm{K}$. The maximum and minimum temperature ranges during the period of experimentation were $24.16-35.68{ }^{\circ} \mathrm{C}$ and 11.06 $25.31{ }^{\circ} \mathrm{C}$ respectively with the average rainfall of 221.53 $\mathrm{mm}$ for both of the years. The experiment was conducted in a split plot design, comprised of 4 different dates of sowing viz. $1^{\text {st }}$ December, $15^{\text {th }}$ December, 30 $0^{\text {th }}$ December and $14^{\text {th }}$ January) as main plot treatments and three nonchemical weed management practices viz. Unweeded check as a control, Hand weeding and Weeding by using Japanese Paddy Weeder in sub-plot treatments and was replicated thrice. Therefore total twelve treatment combinations were tested to find out interaction effect between different time of crop establishment and non-chemical weed management practices. The rice variety IET-4786 (Satabdi) was used in the experiment. The experimental field was ploughed twice with the help of power tiller before the wetting of the field. Again the field was ploughed twice under standing water by power tiller to make the land well puddled and levelled. Before final land preparation, weeds and previous crop stubbles were removed from the field. One ploughing followed by laddering was done just before sowing of the crop. The size of the individual plot was $5 \times 4 \mathrm{~m}^{2}$. Fertilizer dose applied in the field was $120 \mathrm{~kg}$ nitrogen $(\mathrm{N}), 60 \mathrm{~kg} \mathrm{P}_{2} \mathrm{O}_{5}(\mathrm{P})$ and $40 \mathrm{~kg} \mathrm{~K} \mathrm{O}_{2}(\mathrm{~K})$ in the form of urea, single super phosphate and muriate of potash respectively. Half dose of nitrogen (N) and full dose of phosphate $(\mathrm{P})$ and potassium $(\mathrm{K})$ were applied as basal just before each sowing and rest nitrogen was top dressed in two equal split doses viz. 20 and 40 days after sowing. The sun-dried seeds were soaked in clean water for about 24 hours followed by incubation for 2-3 days depending on temperature. Just-sprouted seeds were sown by the drumseeder on well prepared puddled field in rows. One presowing and thereafter irrigation was given as per requirement of the crop. Weeds were controlled through non-chemical methods i.e. hand weeding/manual weeding and weeding by Japanese paddy weeder/mechanical weeding in between the crop row as per treatment. No plant protection measure was taken as because disease and insect pest were below threshold level (BTL). All the treatments were randomly allocated to different plots in each replication. Data on weed dynamics (density and dry matter weight) were taken at 30 and 60 days after sowing (DAS) by placing a $0.5 \times 0.5 \mathrm{~m}^{2}$ quadrat randomly at two locations in each plot. Weed density was measured category wise, i.e., grass, sedge and broad-leaf. The weed biomass was recorded after drying in an oven at $70{ }^{\circ} \mathrm{C}$ for 48 hours. Harvesting was done by using sickle and then the harvested crop was left as such in the field for 1-2 days for sun-drying. The threshing was done separately for each plot by paddy thresher. After cleaning and sun drying the data on grain and straw yield were recorded. All other agronomic practices, except treatment requirements, were done as and when necessary for the crop. Cost of various inputs and crop management practices in producing the crops including the treatment cost and the price of the produce estimated as per available market price. Cost of cultivation, value of produce, net return and benefit: Cost ratios of the crop for various treatments calculated thereafter.The standard error of mean $[\mathrm{SEm} \pm]$ and critical difference $(\mathrm{CD})$ values at $p=0.05$ were used to determine the significance difference between the mean values.

\section{Results and Discussion}

\subsection{Effectof treatments on weed}

Different weed flora of the experimental site comprised of Echinochloa colona, Echinochloa crusgalli, Cynodon dactylon and Leersia hexandra among the grasses; Cyperus iria, Cyperus difformis, Cyperus rotundus and Fimbristylis miliacea in sedges and Ludwigia parviflora, Eclipta alba, Ammania baccifera, Marsilea quadrifoliata and Commelina benghalensis among broad leaf weeds. The results from the 
Table 1 suggested that total weed density (grass, broad leaf and sedge) were significantly influenced by sowing time and weed management practices. Among the different date of sowing, maximum weed density $\mathrm{m}^{-2}$ were recorded at 30 $\left(33.30 \mathrm{~m}^{-2}\right)$ and 60 DAS $\left(42.20 \mathrm{~m}^{-2}\right)$ when rice were sown late i.e. on $30^{\text {th }}$ December compared with other sowing time. Further, sowing on $14^{\text {th }}$ January recorded significantly higher weed population $\mathrm{m}^{-2}$ than $1^{\text {st }}$ and $15^{\text {th }}$ December sowing,

Table 1: Effect of treatments on total weed population, total weed dry matter, yield components and economics of drumseeded boro rice (Pooled data of two years)

\begin{tabular}{|c|c|c|c|c|c|c|c|c|c|c|c|c|c|c|}
\hline \multirow[t]{2}{*}{ Trts. } & \multicolumn{2}{|c|}{$\begin{array}{c}\text { Total weed } \\
\text { popu- } \\
\text { lation } \\
\mathrm{m}^{-2}\end{array}$} & \multicolumn{2}{|c|}{$\begin{array}{c}\text { Total } \\
\text { Weed dry } \\
\text { matter } \\
\left(\mathrm{g} \mathrm{m}^{-2}\right)\end{array}$} & \multirow[t]{2}{*}{$\begin{array}{l}\text { No. of } \\
\text { tillers } \\
\mathrm{m}^{-2}\end{array}$} & \multirow[t]{2}{*}{$\begin{array}{l}\text { No. of } \\
\text { effe- } \\
\text { ctive } \\
\text { tillers } \\
\mathrm{m}^{-2}\end{array}$} & \multirow[t]{2}{*}{$\begin{array}{l}\text { No. of } \\
\text { filled } \\
\text { grains } \\
\text { pani- } \\
\text { cle }^{-1}\end{array}$} & \multirow[t]{2}{*}{$\begin{array}{c}\text { Grain } \\
\text { Yield } \\
(\mathrm{t} \\
\left.\mathrm{ha}^{-1}\right)\end{array}$} & \multirow[t]{2}{*}{$\begin{array}{c}\text { Straw } \\
\text { Yield } \\
(\mathrm{t} \\
\left.\mathrm{ha}^{-1}\right)\end{array}$} & \multirow{2}{*}{$\begin{array}{l}\text { Cost } \\
\text { of } \\
\text { culti- } \\
\text { vation } \\
\text { (₹ } \\
\left.\mathrm{ha}^{-1}\right)\end{array}$} & \multirow[t]{2}{*}{$\begin{array}{c}\text { Treat- } \\
\text { ment } \\
\text { cost } \\
(₹ \\
\left.\text { ha }^{-1}\right)\end{array}$} & \multirow[t]{2}{*}{$\begin{array}{l}\text { Gross } \\
\text { return } \\
(₹ \\
\left.\mathrm{ha}^{-1}\right)\end{array}$} & \multirow[t]{2}{*}{$\begin{array}{c}\text { Net } \\
\text { profit (₹ } \\
\left.\text { ha }^{-1}\right)\end{array}$} & \multirow[t]{2}{*}{$\begin{array}{c}\mathrm{B}: \mathrm{C} \\
\text { ratio }\end{array}$} \\
\hline & $\begin{array}{c}30 \\
\text { DAS }\end{array}$ & $\begin{array}{c}60 \\
\text { DAS } \\
\end{array}$ & $\begin{array}{c}30 \\
\text { DAS } \\
\end{array}$ & $\begin{array}{c}60 \\
\text { DAS }\end{array}$ & & & & & & & & & & \\
\hline \multicolumn{15}{|c|}{ Date of Sowing } \\
\hline $\mathrm{D}_{1}$ & 28.15 & 35.36 & 18.30 & 22.73 & 346.41 & 308.16 & 74.91 & 5.19 & 5.65 & 20131 & 2166 & 42116 & 21985 & 0.97 \\
\hline $\mathrm{D}_{2}$ & 27.46 & 34.61 & 18.28 & 22.43 & 326.04 & 301.65 & 74.80 & 5.07 & 5.41 & 20131 & 2166 & 41333 & 21201 & 1.03 \\
\hline $\mathrm{D}_{3}$ & 33.30 & 42.20 & 21.30 & 24.42 & 237.06 & 213.31 & 59.61 & 2.84 & 3.29 & 20131 & 2166 & 22740 & 7825 & 0.36 \\
\hline $\mathrm{D}_{4}$ & 32.69 & 42.15 & 20.62 & 23.67 & 236.74 & 215.46 & 68.20 & 3.32 & 3.68 & 20131 & 2166 & 26546 & 19245 & 0.89 \\
\hline $\begin{array}{l}\text { SEm } \\
\pm\end{array}$ & 0.16 & 0.19 & 0.04 & 0.11 & 2.89 & 1.11 & 0.22 & 0.02 & 0.02 & - & - & - & - & - \\
\hline $\mathrm{CD}$ & 0.69 & 0.83 & 0.19 & 0.48 & 13.05 & 5.01 & 1.00 & 0.11 & 0.09 & - & - & - & - & - \\
\hline \multicolumn{15}{|c|}{ Method of weed management } \\
\hline $\mathrm{W}_{1}$ & 54.68 & 66.08 & 46.96 & 55.09 & 233.06 & 202.22 & 60.94 & 2.75 & 3.24 & 17965 & - & 22020 & 16220 & 0.23 \\
\hline $\mathrm{W}_{2}$ & 17.23 & 23.45 & 6.04 & 7.58 & 307.04 & 284.89 & 73.47 & 4.71 & 5.09 & 21865 & 3900 & 38277 & 16412 & 0.75 \\
\hline $\mathrm{W}_{3}$ & 19.88 & 26.21 & 6.26 & 7.87 & 319.57 & 291.82 & 73.74 & 4.85 & 5.19 & 20565 & 2600 & 39255 & 18690 & 0.91 \\
\hline $\begin{array}{c}\text { SEm } \\
( \pm)\end{array}$ & 0.93 & 0.94 & 0.06 & 0.09 & 2.93 & 1.09 & 0.18 & 0.01 & 0.01 & - & - & - & - & - \\
\hline $\mathrm{CD}$ & 2.81 & 2.83 & 0.17 & 0.29 & 8.81 & 3.29 & 0.54 & 0.03 & 0.03 & - & - & - & - & - \\
\hline
\end{tabular}

DAS: Days after Sowing; DAT: Days after Transplanting; $\mathrm{D}_{1}: 1^{\text {st }}$ December; $\mathrm{D}_{2}: 15^{\text {th }}$ December; $\mathrm{D}_{3}: 30^{\text {th }}$ December; $\mathrm{D}_{4}$ : $14^{\text {th }}$ January; $\mathrm{W}_{1}$ : Unweeded check; $\mathrm{W}_{2}$ : Hand weeding; $\mathrm{W}_{3}$ : Weeding by Japanese Paddy Weeder; ${ }^{*}=0.05$

but lower than $30^{\text {th }}$ December sowing. Though sowing on $1^{\text {st }}$ December and $15^{\text {th }}$ December was statistically at per at both 30 and 60 DAS, but sowing on $15^{\text {th }}$ December gave the lowest $\left(27.46 \mathrm{~m}^{-2}\right)$ weed count. Weed density is influenced by seeding time as more weed density ( 51 to 59 plants $\mathrm{m}^{-2}$ ) was recorded when rice was seeded late compared to early seeding (Mubeen et al., 2014). All weed management treatments were effective for reducing weed density over non treated control at 30 and 60 DAS. Hand-weeding treatment gave the lowest weed density at 30 and 60 DAS $\left(17.23 \mathrm{~m}^{-2}\right.$ and 23.45 $\mathrm{m}^{-2}$ respectively) compared with other weed management practices. Weeding by Japanese Paddy Weeder were second best treatment and it was comparable with weeding by Japanese Paddy Weeder treatment at both 30 and 60 DAS. The same trends were observed in case of total weed dry matter i.e. altogether of grasses, broad leaves and sedges $\mathrm{m}^{-2}$.

\subsection{Interaction effect of the treatments on weed}

Significant interaction effects between different dates of sowing and non-chemical weed management methods were observed regarding total weed population and weed biomass at both the observations (30 and 60 DAS). The maximum weed population $\mathrm{m}^{-2}$ (56.46 and $113.58 \mathrm{~m}^{-2}$ at 30 and $60 \mathrm{DAS}$ respectively) was obtained from the control plot of weed management method (un-weeded check) of $30^{\text {th }}$ December sowing $\left(\mathrm{D}_{3} \mathrm{~W}_{1}\right)$ at both of the observations. Similarly highest total weed dry matters were recorded from the un-weeded weed management treatment of $30^{\text {th }}$ December sowing date $\left(\mathrm{D}_{3} \mathrm{~W}_{1}\right)$ at $30 \mathrm{DAS}\left(48.99 \mathrm{~g} \mathrm{~m}^{-2}\right)$ and $14^{\text {th }}$ January sowing date $\left(\mathrm{D}_{4} \mathrm{~W}_{1}\right)$ at $60 \mathrm{DAS}\left(56.50 \mathrm{~g} \mathrm{~m}^{-2}\right)$. Significantly lowest weed populations were observed on $15^{\text {th }}$ December sowing with hand weeding $\left(\mathrm{D}_{2} \mathrm{~W}_{2}\right)$ treatment combinations at all observations (30 and 60 DAS) followed by sowing on $1^{\text {st }}$ December with 
hand weeding $\left(\mathrm{D}_{1} \mathrm{~W}_{2}\right)$, which was statistically comparable with $15^{\text {th }}$ December sowing with Japanese Paddy Weeder weeding. Lowest total weed dry weights were recorded from $1^{\text {st }}$ December sowing with hand weeding $\left(D_{1} W_{2}\right)$ at 30 days after sowing $\left(5.20 \mathrm{~g} \mathrm{~m}^{-2}\right)$ and $14^{\text {th }}$ January sowing with hand weeding treatment combination $\left(\mathrm{D}_{1} \mathrm{~W}_{2}\right)$ at 60 days after sowing $\left(7.12 \mathrm{~g} \mathrm{~m}^{-2}\right)$, which were closely followed by $15^{\text {th }}$ December sowing with hand weeding $\left(\mathrm{D}_{2} \mathrm{~W}_{2}\right)$ treatment combinations (5.25 and $7.24 \mathrm{~g} \mathrm{~m}^{-2}$ respectively). Irrespective of weed management methods, increasing trend of weed population and dry weight were observed with delayed sowing date. Jadhav, 2013, reported that delay in sowing results in slow growth of crop and increased infestation of competing weeds.

\subsubsection{Effect of treatments on yield and yield attributes}

Among the different date of sowing, $1^{\text {st }}$ December sowing produced the highest number of tillers, effective tillers and filled grains panicle ${ }^{-1}(346.41,308.16$ and 74.91 respectively) followed by $30^{\text {th }}$ December sowing date. The minimum number of tillers $\left(236.74 \mathrm{~m}^{-2}\right)$ was recorded from $14^{\text {th }}$ January sowing. $30^{\text {th }}$ December sowing date produced the lowest number of effective tillers and filled grains panicle ${ }^{-1}(213.31$ and 59.61 respectively). In case of weed management practices, mechanical weeding with Japanese Paddy Weeder showed the superiority over hand weeding method and produced the highest number of tillers and effective tillers $\mathrm{m}^{-2}$ and filled grains panicle ${ }^{-1}$. Early sowing time ( $1^{\text {st }}$ December $)$ resulted higher grain yield compared to the sowing on second week of January (Table 1). The grain yield improved with weed management treatments and there was a variation for grain yield among non-chemical weed control treatments. Compared to non-treated control, all weed management treatments resulted 41.61 to $43.29 \%$ higher grain yields may be due to the less crop weed competition at different growth stages of crop. Among different date of sowing highest grain yield (5.19 $\left.\mathrm{t} \mathrm{ha}^{-1}\right)$ was obtained from $1^{\text {st }}$ December sowing, which was almost statistically equal with sowing on $15^{\text {th }}$ December. The highest grain yield $\left(4.85 \mathrm{t} \mathrm{ha}^{-1}\right)$ was recorded from the treatment of weeding with Japanese Paddy Weeder followed by hand weedingtreatment. The same trendsof data were observed in case of straw yield.

\subsubsection{Interaction effect of the treatments on yield and yield attributes}

From the data presented in the Table 2, it is found that 1 st December sowing and hand weeding $\left(\mathrm{D}_{1} \mathrm{~W}_{2}\right)$ combination produced significantly highest number ofeffective tillers $\mathrm{m}^{-2}$ (382.61), which was statistically at par (377.32) with weeding by Japanese paddy weeder treatment combination $\left(\mathrm{D}_{1} \mathrm{~W}_{3}\right)$. Same trend was observed in number of effective tillers $\mathrm{m}^{-2}(345.32)$ at $1^{\text {st }}$ December sowing, where Japanese paddy weeder treatment combination showed the superiority over hand weeding treatment combination. Highest number of filled grains panicle ${ }^{-1}$ (79.73) was obtained from sowing on $1^{\text {st }}$ December and Japanese paddy weeder weeding combination $\left(\mathrm{D}_{1} \mathrm{~W}_{3}\right)$, which was also at par (78.17) with hand weeding treatment combination $\left(\mathrm{D}_{1} \mathrm{~W}_{2}\right)$ at the same date of sowing and sowing on $15^{\text {th }}$ December with hand weeding treatment combination $\left(\mathrm{D}_{2} \mathrm{~W}_{2}\right)$. On the other hand, sowing on $30^{\text {th }}$ December with unweeded treatment combination $\left(\mathrm{D}_{3} \mathrm{~W}_{1}\right)$ gave significantly lowest number of filled grains panicle $^{-1}$ (53.62). From the presented data it is also observed that $1^{\text {st }}$ December sowing with Japanese paddy weeder weeding $\left(\mathrm{D}_{1} \mathrm{~W}_{3}\right)$ combination recorded significantly highest grainyield $\left(6.07 \mathrm{t} \mathrm{ha}^{-1}\right)$ and statistically at par $\left(6.06 \mathrm{t} \mathrm{ha}^{-}\right.$ $\left.{ }^{1}\right)$ with $15^{\text {th }}$ December sowing and Japanese paddy weeder weeding combination $\left(\mathrm{D}_{2} \mathrm{~W}_{3}\right)$. Maximum straw yield (6.48 t ha ${ }^{-1}$ ) obtained from $1^{\text {st }}$ December sowing with Japanese paddy weeder weeding $\left(\mathrm{D}_{1} \mathrm{~W}_{3}\right)$ combination. The lowest grain $\left(2.02 \mathrm{tha}^{-1}\right)$ and straw yield $\left(2.46 \mathrm{tha}^{-1}\right)$ was obtained from $30^{\text {th }}$ December sowing along with un-weeded treatment combination $\left(\mathrm{D}_{3} \mathrm{~W}_{1}\right)$.

\subsubsection{Effect of the treatments on economics}

There were no differences in cost of cultivation and treatment cost between the treatments of different time of sowing. But in case of weed management treatments, hand weeding treatment required maximum cost (₹ $3900 \mathrm{ha}^{-1}$ ) than other treatments. Though the maximum gross return and net profit (₹ 42116.67 and $21985 \mathrm{ha}^{-1}$ respectively) came from the $1^{\text {st }}$ December sowing which were followed by $15^{\text {th }}$ December sowing, but highest $\mathrm{B}: \mathrm{C}$ ratio (1.03) was obtained from $15^{\text {th }}$ December sowing date. Among different weed management treatments, weeding by Japanese paddy weeder gave the maximum gross return, net profit and B:C ratio ( $₹ 39255$, 18690 and 0.91 ha $^{-1}$ respectively).

\subsubsection{Interaction effect of the treatments on economics}

From the Table 3, it is clear that among different treatment combinations, cost of cultivation and treatment cost varied with different weed management practices where there were no variations in between different date of sowing. Highest gross return, net profit and B:C ratio (₹ 49830, ₹ 29,265 haand $1.41 \mathrm{ha}^{-1}$ respectively) were obtained from $1^{\text {st }}$ December sown boro rice coupled with Japanese paddy weeder weeding $\left(\mathrm{D}_{1} \mathrm{~W}_{3}\right)$ followed by $15^{\text {th }}$ December sowing combined with weeding by Japanese paddy weeder $\left(\mathrm{D}_{2} \mathrm{~W}_{3}\right)$ may be due to the minimise of weed problem and maximise the crop growth and yield. The lowest gross return, net profit and also B:C ratio recorder from the $30^{\text {th }}$ December sowing with no weed management $\left(\mathrm{D}_{3} \mathrm{~W}_{1}\right)$ followed by $14^{\text {th }}$ January sowing with no weed management $\left(\mathrm{D}_{3} \mathrm{~W}_{1}\right)$ treatment combinations, which 
Table 2: Interaction effect of different treatments on yield, yield components and economics of drum-seeded boro rice (Pooled data of two years)

\begin{tabular}{|c|c|c|c|c|c|c|c|c|c|c|c|c|c|c|}
\hline \multirow{2}{*}{$\begin{array}{l}\text { Treat- } \\
\text { ments } \\
\text { combi- } \\
\text { nations }\end{array}$} & \multicolumn{2}{|c|}{$\begin{array}{c}\text { Total Weed } \\
\text { population } \\
\mathrm{m}^{-2}\end{array}$} & \multicolumn{2}{|c|}{$\begin{array}{l}\text { Total Weed } \\
\text { dry matter } \\
\quad\left(\mathrm{g} \mathrm{m}^{-2}\right)\end{array}$} & \multirow[t]{2}{*}{$\begin{array}{c}\text { No. of } \\
\text { tillers } \\
\mathrm{m}^{-2}\end{array}$} & \multirow{2}{*}{$\begin{array}{c}\text { No. of } \\
\text { effec- } \\
\text { tive } \\
\text { tillers } \\
\mathrm{m}^{-2}\end{array}$} & \multirow{2}{*}{$\begin{array}{l}\text { No. of } \\
\text { filled } \\
\text { grains } \\
\text { pani- } \\
\text { cle }^{-1}\end{array}$} & \multirow[t]{2}{*}{$\begin{array}{c}\text { G.Y. } \\
(\mathrm{t} \\
\left.\mathrm{ha}^{-1}\right)\end{array}$} & \multirow[t]{2}{*}{$\begin{array}{l}\text { S.Y. } \\
\left(\mathrm{th}^{-1}\right)\end{array}$} & \multirow[t]{2}{*}{$\begin{array}{l}\text { Cost of } \\
\text { culti- } \\
\text { vation } \\
\left(₹ \mathrm{ha}^{-1}\right)\end{array}$} & \multirow[t]{2}{*}{$\begin{array}{l}\text { Treat- } \\
\text { ment } \\
\text { cost } \\
\left(₹ \mathrm{ha}^{-1}\right)\end{array}$} & \multirow[t]{2}{*}{$\begin{array}{l}\text { Gross } \\
\text { return } \\
\left(₹ \mathrm{ha}^{-1}\right)\end{array}$} & \multirow[t]{2}{*}{$\begin{array}{c}\text { Net } \\
\text { profit } \\
(₹ \\
\left.\text { ha }^{-1}\right)\end{array}$} & \multirow[t]{2}{*}{$\begin{array}{l}\mathrm{B}: \mathrm{C} \\
\text { ratio }\end{array}$} \\
\hline & $\begin{array}{c}30 \\
\text { DAS }\end{array}$ & $\begin{array}{c}60 \\
\text { DAS }\end{array}$ & $\begin{array}{c}30 \\
\text { DAS }\end{array}$ & $\begin{array}{c}60 \\
\text { DAS }\end{array}$ & & & & & & & & & & \\
\hline $\mathrm{D}_{1} \mathrm{~W}_{1}$ & 49.85 & 95.69 & 44.37 & 53.25 & 279.29 & 238.64 & 66.81 & 3.51 & 4.05 & 17965 & - & 27950 & 9985 & 0.56 \\
\hline $\mathrm{D}_{2} \mathrm{~W}_{1}$ & 50.42 & 96.49 & 45.75 & 54.75 & 255.48 & 228.67 & 65.99 & 3.32 & 3.82 & 17965 & - & 27300 & 9335 & 0.52 \\
\hline $\mathrm{D}_{3} \mathrm{~W}_{1}$ & 59.46 & 113.58 & 48.99 & 55.81 & 200.15 & 171.75 & 53.62 & 2.02 & 2.46 & 17965 & - & 16280 & -1685 & -0.09 \\
\hline $\mathrm{D}_{4} \mathrm{~W}_{1}$ & 59.01 & 112.76 & 48.75 & 56.50 & 197.30 & 169.83 & 57.31 & 2.15 & 2.62 & 17965 & - & 16550 & -1415 & -0.08 \\
\hline $\mathrm{D}_{1} \mathrm{~W}_{2}$ & 15.9 & 29.1 & 5.20 & 7.37 & 382.61 & 342.99 & 78.17 & 5.95 & 6.41 & 21865 & 3900 & 48570 & 26705 & 1.22 \\
\hline $\mathrm{D}_{2} \mathrm{~W}_{2}$ & 14.69 & 26.9 & 5.25 & 7.24 & 349.50 & 330.97 & 79.12 & 5.83 & 6.19 & 21865 & 3900 & 47440 & 25575 & 1.17 \\
\hline $\mathrm{D}_{3} \mathrm{~W}_{2}$ & 18.86 & 34.61 & 7.35 & 8.59 & 253.12 & 231.27 & 63.04 & 3.22 & 3.62 & 21865 & 3900 & 25750 & 3885 & 0.18 \\
\hline $\mathrm{D}_{4} \mathrm{~W}_{2}$ & 19.49 & 35.6 & 6.38 & 7.12 & 242.90 & 231.30 & 73.53 & 3.84 & 4.16 & 21865 & 3900 & 31350 & 9485 & 0.43 \\
\hline $\mathrm{D}_{1} \mathrm{~W}_{3}$ & 18.69 & 34.25 & 5.33 & 7.58 & 377.32 & 342.85 & 79.73 & 6.07 & 6.48 & 65 & 2600 & 49830 & 29265 & 1.41 \\
\hline $\mathrm{D}_{2} \mathrm{~W}_{3}$ & 17.3 & 31.71 & 5.35 & 7.41 & 373.02 & 345.32 & 79.30 & 6.06 & 6.21 & 20565 & 2600 & 49260 & 28695 & 1.4 \\
\hline $\mathrm{D}_{3} \mathrm{~W}_{3}$ & 20.98 & 38.35 & 7.56 & 8.81 & 257.90 & 236.89 & 62.18 & 3.27 & 3.78 & 20565 & 2600 & 26190 & 5625 & 0.27 \\
\hline $\mathrm{D}_{4} \mathrm{~W}_{3}$ & 22.57 & 41.38 & 6.75 & 7.41 & 270.02 & 236.24 & 73.75 & 3.98 & 4.27 & 20565 & 2600 & 31740 & 11175 & 0.54 \\
\hline${ }^{\#} \mathrm{SEm} \pm$ & 0.43 & 0.47 & 0.12 & 0.20 & 5.87 & 2.19 & 0.36 & 0.02 & 0.02 & - & - & - & - & - \\
\hline${ }^{\#} \mathrm{SEm} \pm$ & 0.39 & 0.45 & 0.12 & 0.19 & 5.68 & 2.09 & 0.38 & 0.02 & 0.02 & - & - & - & - & - \\
\hline${ }^{\$} \mathrm{CD}$ & 1.29 & 1.41 & 0.36 & 0.59 & 17.61 & 6.57 & 1.08 & 0.06 & 0.06 & - & - & - & - & - \\
\hline${ }^{\$} \mathrm{CD}$ & 1.17 & 1.35 & 0.36 & 0.57 & 17.03 & 6.28 & 1.14 & 0.06 & 0.06 & - & - & - & - & - \\
\hline
\end{tabular}

$\mathrm{D}_{1}: 1^{\text {st }}$ December; $\mathrm{D}_{2}: 15^{\text {th }}$ December; $\mathrm{D}_{3}: 30^{\text {th }}$ December; $\mathrm{D}_{4}: 14^{\text {th }}$ January; $\mathrm{W}_{1}:$ Unweeded check; $\mathrm{W}_{2}:$ Hand weeding; $\mathrm{W}_{3}$ : Weeding by Japanese Paddy Weeder; $\mathrm{D} \times \mathrm{W}$ : Date of sowing $\times$ Weeding method; $\mathrm{W} \times \mathrm{D}$ : Weeding method $\times$ Date of sowing; ${ }^{*}$ Price rate of rice grain=₹ $700.00 \mathrm{q}^{-1}$; Price rate of rice straw $=₹ 100.00 \mathrm{q}^{-1} ;{ }^{\#} \mathrm{D} \times \mathrm{W} ;{ }^{\#} \mathrm{~W} \times \mathrm{D} ;{ }^{\$} \mathrm{D} \times \mathrm{W} ;{ }^{\$ \$} \mathrm{~W} \times \mathrm{D}(p=0.05)$

indicates that there were a positive impact of delayed in sowing time and weed management practice on weed, crop growth and yield as well as on economy of the drum seeded boro rice.

\section{Conclusion}

Sowing of boro riceby using the drum seeder during first fortnight of December along with non-chemical weed management practice by using Japanese paddy weeder could give the satisfactory yield and economic return to the farmers. This combined management practicemay be recommended for the boro rice farmers.

\section{References}

Anwar, M.P., Juraimi, A.S., Puteh, A., Man, A., Rahman, M.M., 2012. Efficacy, phytotoxicity and economics of different herbicides in aerobic rice. Acta Agriculturae Scandinavica, Section B-Soil \& Plant Science 62(7),
604-615.

Ashraf, M.M., Awan, T.H., Manzoor, M., Ahmad, M., Safdar, M.E., 2006. Screening of herbicides for weed management in transplanted rice. Journal of Animaland Plant Sciences 16(1-2), 92.

Bakker, R.R., Bell, M.A., Rickman, J.F., 2002. Mechanization issues in tillage and crop establishment for dry directseeded rice. In: Pandey, S., Motimar, M., Wade, L., Toung, T.P., Lopez, K., Hardy, B. (Eds.), Direct seeding: research issues and opportunities. In: Proceedings of the International Workshop on Direct Seeding in Asian Rice Systems: Strategic Issues and Opportunities, International Rice Research Institute, Philippines, 219.

Balasubramanian, V., Ladha, J.K., Gupta, R.K., Naresh, R.S., Mehla, Singh, B., Singh, Y., 2003. Technology options for rice in the rice-wheat system in South Asia. In: Ladha, J.K. (Ed.), Improving the productivity and sustainability of rice-wheat systems: Issues and impact. American Society of Agronomy Special Publication 65, 
115-147.

Begum, M., Juraimi, A.S., Omar, S.R.S., Rajan,A., Azmi, M., 2008. Effect of herbicides for the control of (Fimbristylis miliacea L.) Vahl. in Rice. Journal of Agronomy 7(3), 251-257.

Chauhan, B.S., Johnson, D.E., 2011. Growth response of direct seeded rice to oxadiazon and bispyribac-sodium in aerobic and saturated soils. Journal of Weed Science 59(1), 119-122.

Chauhan,B.S., Johnson, D.E., 2011. Row spacingand weed control timing affect yield of aerobicrice. Field Crops Research 121, 226-231.

Farooq, M., Siddique, K.H.M., Rehman, H., Aziz, T., Lee, D.J., Wahid, A., 2011. Rice direct seeding: Experiences, challenges and opportunities. Soil Tillage Research $111,87-98$.

FAO, 2004.Rice Biotechnology for Developing Countries in Asia. International Rice Research Institute, Science City of Munoz, Philippines.Available from http://www. fao.org/ rice2004/en/aboutrice.htm.

Gomez, K.A., Gomez, A.A., 1984. Statistical procedures for agricultural research. Second Edition. John Wiley \& Sons, New York, USA.

Heap, I., 2006. The International Survey of Herbicide Resistant Weeds. Available from http://www.weedscience.com.

Hussain, S., Ramzan, M., Akhter, M., Aslam, M., 2008. Weed management in direct seeded rice. Journal of Animal and Plant Sciences 18(2-3), 86-88.

Jadhav, A.S., 2013. Sowing time-a tool for weed control in direct-seeded upland rice. Indian Journal of Weed Science 45(1), 16-18.

Liebman, M., Mohler, C.L., Staver, C.P., 2001. Ecological management of agricultural weeds. Cambridge University Press, Cambridge, 532.
Maclean, J.L., Dawe, D.C., Hardy, B., Hettel, G.P., 2002. Rice Almanac. Los Banos (Philippines): International Rice Research Institute, Bouaké (Cote d'lvoire): West Africa Rice Development Association, Cali (Colombia): International Center for Tropical Agriculture, Rome (Italy): Food and Agriculture Organization, 253.

Mamun, A.A., Karim, S.M.R., Begum, M., Uddin, M.I. and Rahim, M.A. 1993. Weed survey in different crops under three agro ecological zones of Bangladesh. BAURES Progress 8, 41-51.

Marwat, K.B., Saeed, M., Gul, B., Hussain, Z., 2006. Performance of different herbicides in wheat (Triticum aestivum L.) under rainfed conditions of Kohat. PakistanJournal of Weed Science Research 12(3),163-168.

Mishri, L.S., Kailash, P.B., 2005. Response of wets eeded rice varieties to sowing dates. Nepal Agricultural Research Journal 6, 35.

Moody, K., Cordova, V.G., 1985. Wet-seeded Rice.In: Women in rice farming. International Rice Research Institute, Los Banos, Philippines, 467-480.

Mubeen, K., Nadeem, M.A., Tanveer, , A., Jhala, A.J., 2014. Effects of seeding time and weed control methods in direct seededrice (Oryza sativa L.). The Journal of Animal \& Plant Sciences 24(2), 534-542.

Oerke, E.C., Dehne, H.W., 2004. Safeguarding productionLosses in major crops and the role of crop protection. Crop Production 23(4), 275-285.

Phuong, L.T., Denich, M., Vlek, P.L.G., Balasubramanian, V., 2005. Suppressing weeds in direct seeded lowland rice: effects of methods and rates of seeding. Journal of Agronomyand Crop Science 191(3), 185-194.

Roder, W., Keobulapha, B., 1997. Weeds in slash-and-burn rice fields in northern Laos. Weed Research 37(2), 111-119. 